\title{
Produzir na reprodução: um olhar sobre a renovação da força de trabalho escrava no Brasil oitocentista
}

\author{
Producing in reproduction: a close look to the \\ renewing of enslaved labor-power in nineteenth- \\ century Brazil
}

\section{Gabriela Salcedo Figueira ${ }^{a}$}

\begin{abstract}
Resumo Por meio de uma análise documental de manuais de agricultura brasileiros escritos no século XIX por senhores de escravos, procura-se identificar o caráter específico da reprodução social da escravidão. Argumenta-se que esse caráter está assente na união das esferas produtiva e reprodutiva, e não unicamente num modo de repor a força de trabalho escrava.
\end{abstract}

Palavras-chave Economia-mundo capitalista. Escravidão. Força de trabalho. Manuais de agricultura. Teoria da reprodução social.

\begin{abstract}
This paper conducts a document analysis of Brazilian agriculture manuals written in the 19th century by slave owners, investigating the specific character of slavery social reproduction. It is argued that this character is based on the union of the productive and reproductive spheres, and not only on a mode of replacing the enslaved labor-power.
\end{abstract}

Keywords Capitalist world-economy. Slavery. Labor-power. Agriculture manuals. Social reproduction theory.

\section{INTRODUÇÃO: A TEORIA DA REPRODUÇÃO SOCIAL E A ESCRAVIDÃO}

A teoria da reprodução social (TRS) entende que a opressão da mulher na sociedade contemporânea finca sua raiz e é nutrida pelo sistema em que se manifesta, o capitalista. Ao defender que essa opressão faz parte da estrutura do capitalismo, a precursora dessa teoria, Lise Vogel (2013 [1983]), afirma que o marxismo é capaz de fornecer argumentos suficientes para tal constatação. Isso não equivale a dizer que Karl Marx abordou perfeita e explicitamente a questão da axial opressão feminina na sociedade de classes capitalista, mas sim que a partir das regras gerais de

a Mestre e doutoranda em Sociologia pela Universidade do Minho. Atualmente, realiza um estudo comparado sobre a reprodução da escravidão no Brasil e nos Estados Unidos do século XIX. 
funcionamento do capitalismo identificadas pela teoria marxiana pode-se explicar e localizar a particular opressão sofrida pelas mulheres nesse sistema social.

Partindo da premissa de que "todo processo social de produção é simultaneamente processo de reprodução" (Marx, 2011 [1867], p. 780), a teórica assegura que a referida opressão deriva do indispensável papel desempenhado pelas mulheres no processo de reprodução. Mais detalhadamente: segundo Marx (2011 [1867]), qualquer sociedade só pode perseverar ao longo da história se ao mesmo tempo que produz também se reproduza, i.e., que no modo de produção de determinada sociedade também se produza as condições de sua reprodução. Logo, é fundamental produzir artigos que serão utilizados como meios de uma produção futura para além dos de consumo imediato. Ele afirma ainda que se o processo de produção se realiza de modo capitalista, o processo de reprodução também.

Uma vez que o capitalismo se organiza para a acumulação sem fim de capital e o capital é obtido por meio da exploração da força de trabalho da classe trabalhadora, o trabalhador é um dos meios de produção que precisa ser perenemente reproduzido.

O proprietário da força de trabalho é mortal. Portanto, para que sua aparição no mercado de trabalho seja contínua, como pressupõe a contínua transformação do dinheiro em capital, é preciso que o vendedor da força de trabalho se perpetue, "como todo indivíduo vivo se perpetua pela procriação". As forças de trabalho retiradas do mercado por estarem gastas ou mortas têm de ser constantemente substituídas, no mínimo, por uma quantidade igual de força de trabalho (Marx, 2011 [1867], p. 318).

De acordo com Marx (2011 [1987], p. 787), essa "constante reprodução ou perpetuação do trabalhador é a sine qua non da produção capitalista”. Porém, para ele, a procriação de portadores de força de trabalho ocorre de forma puramente natural. Destarte, apesar de o processo de reprodução ser intrínseco ao processo de produção, dentro daquele, o teórico contabiliza apenas a produção das condições materiais para a reprodução dos trabalhadores, sem integrar o trabalho nela envolvido. Diz ele: "O capitalista pode abandonar confiadamente o preenchimento dessa condição ao impulso de autoconservação e procriação dos trabalhadores" (Marx, 2011 [1867], p. 789).

Pelas linhas de Marx, Vogel (2013 [1983]) afirma que não é bem assim: à exceção da fisiologia da procriação, a reprodução dos trabalhadores é um processo social e histórico que carrega as características do sistema social em que está inse- 
rido. Alega que as mulheres são oprimidas no capitalismo porque são as únicas capazes de produzir os portadores de força de trabalho, já que são elas que possuem a qualidade inata da reprodução de trabalhadores: a capacidade de gestar, de parir e de amamentar. Ora, reflete ela, se na base do modo de produção capitalista está o trabalhador de quem se apropria a mais-valia, na base da produção desses portadores de força de trabalho estão as mulheres.

No seu entender, a capacidade reprodutiva das mulheres é uma condição para a reprodução social do capitalismo, porque garante a substituição futura da força de trabalho que vem a se tornar inoperante. Por isso, o capitalismo desenvolve aparatos e mecanismos para controlar o corpo das mulheres e garantir a constante reprodução de trabalhadores a medida da demanda do processo produtivo. Entre eles, localizam-se políticas reprodutivas, formas de família e de criação de crianças, o ordenamento de gênero e até o cariz heteronormativo do sistema (Ferguson, McNally, 2017, p. 36).

Vogel (2013 [1983]) argumenta que o processo de reprodução de trabalhadores não é tal qual um processo de produção capitalista, em que existe uma relação de exploração direta entre o capitalista explorador e a trabalhadora explorada, de quem o explorador se apropria da mais-valia. A reprodução de força de trabalho é executada numa esfera à parte da produtiva e envolve três tipos de atividades: (i) regeneração dos trabalhadores, tais como alimentação, higiene, cuidados psíquicos e afetivos; (ii) criação e cuidado daqueles que ainda não se dispõem ao mercado de trabalho e dos que dele já saíram, as crianças, os desempregados, os idosos etc.; e (iii) a reprodução biológica de novos trabalhadores, isto é, a procriação (Bhattacharya, 2019).

Essas atividades são realizadas, em regra, na esfera doméstica ou, como aqui denominada, na esfera reprodutiva. A reprodução de trabalhadores é feita às margens da economia formal e a um baixo custo para o capital, mas isso não significa que aquela esfera esteja livre ou independente do capital (Bhattacharya, 2019). Para Vogel (2013 [1983]), embora identifiquem-se as duas esferas na sociedade capitalista, a produtiva onde se realiza a produção de mercadorias, e a esfera doméstica, onde se realiza a reprodução da força de trabalho, uma não é autônoma da outra. Pelo contrário, o trabalho reprodutivo é parte do trabalho necessário à reprodução dos trabalhadores na sociedade capitalista, ocorre fora da esfera da produção, mas é a ela subordinado.

Falar que o trabalho reprodutivo se realiza fora da economia formal equivale a dizer que "o trabalho no lar não é mercantilizado, ele produz valores de uso, não mercadorias cuja venda realiza mais-valor para o capitalista” (Ferguson, McNally, 
2017, p. 35). Apesar de na esfera reprodutiva serem produzidos portadores de força de trabalho, importa reforçar que a força de trabalho em si não é uma mercadoria. Como constata Marx (2011 [1867], p. 313), "a força de trabalho só pode aparecer como mercadoria no mercado na medida em que é colocada à venda ou é vendida pelo seu próprio possuidor, pela pessoa da qual ela é a força de trabalho”.

Então, à luz da teoria da reprodução social, ao reproduzir um portador de força de trabalho, as mulheres não estão produzindo diretamente valor de troca ao capital, mas sim valor de uso que pode vir a ser uma mercadoria. Assim, Vogel conclui que a opressão da mulher não se realiza porque ela produz um valor ao capital dentro de uma esfera doméstica na qual é explorada sem ser paga. Mas, sim, porque tal trabalho que resulta em portadores de força de trabalho é "uma condição essencial que reforça a dinâmica do sistema capitalista, possibilitando que o capitalismo se reproduza" (Ferguson, McNally, 2017, p.35).

Contudo, essa interpretação não é unânime dentro da perspectiva da reprodução social. A corrente teórica desenvolvida pelo feminismo operário costuma levar a uma leitura de que o trabalho reprodutivo, afinal, produz valor de troca ao capital (Arruzza, 2010; Curcio, 2020). Vê-se, pois, que as divergências entre as teorias estão assentes na interpretação e críticas que realizam sobre a teoria do valor em Marx. Por essa vertente, explica-se que no capitalismo, o trabalho social se dividiu em duas esferas, sendo que a esfera da reprodução da vida deixa o plano público e passa a ser questão privada de cada agregado familiar. Os trabalhadores, por sua vez, se dividem entre aqueles que vendem a sua força de trabalho e aqueles que estão organizados para possibilitar a venda do trabalho do outro (Dalla Costa, 1972).

Neste sentido, Dalla Costa (1972) e Federici (1975) explicam que, no modelo assalariado do capitalismo, o salário dos explorados comanda o trabalho doméstico não pago. Logo, o capital domina por meio do salário, mas esse domínio não fica restrito apenas aos assalariados, já que também se incide sobre o trabalho doméstico majoritariamente executado por mulheres donas de casa e assalariadas. Responsáveis pelas atividades de manutenção e regeneração dos seus familiares, é pelo modelo funcional da família operária que as mulheres têm o seu trabalho inviabilizado, em que apenas o produto de suas atividades torna-se visível e valorado, o trabalhador no trabalho produtivo (Dalla Costa, 1972). Na mesma direção, Federici (2017) afirma que a família operária é um mecanismo que se institui com o capitalismo como forma de apropriação e ocultação do trabalho das mulheres. Deste modo, o sistema capitalista se beneficia ao explorar um trabalho reprodutivo produtor de mercadorias - força de trabalho e demais bens de consumo - como um 
trabalho não produtivo e não pago, já que executado dentro do universo privado da família (Federici, 2017; 2021; Dalla Costa, 1972).

Voltando à TRS e a Vogel (2013 [1983]), que não exigem uma reformulação da concepção do valor, essa autora cautela que a esfera doméstica familiar não é o único espaço em que os trabalhadores podem ser reproduzidos. Há de se considerar a renovação de trabalhadores realizada em outras instituições além da família, como é o caso dos dormitórios e acampamentos de trabalhadores. Quanto à reposição da força de trabalho, a autora diz que há outras formas de se angariar trabalhadores disponíveis ao mercado de trabalho e dá como exemplo a imigração e a escravidão, ponderando a instituição escravista como um processo exógeno de reprodução, isto é, trabalhadores que vieram de uma arena externa àquela em que geograficamente executam suas funções.

Sintética quanto ao tema, pode-se dizer que Vogel (2013 [1983]) classifica a escravidão apenas como uma forma de repor força de trabalho e não como um processo reprodutivo específico e intrínseco a um modo de produção também específico, com características próprias: histórica, geográfica e socialmente situadas. Contudo, ao amparar-se na TRS, o objetivo deste artigo não é demonstrar que o pensamento da teórica é insuficiente para abordar a escravidão, uma vez que se reconhece que a teoria foi desenvolvida em observação ao modelo produtivo assalariado. Acredita-se que, a partir do percurso traçado pelas feministas da reprodução social para o entendimento da opressão das mulheres nesse modelo, será possível perceber como se dava o processo reprodutivo da escravidão e o que há nele que é somente dele. Ou seja, a TRS está aqui para ajudar a direcionar o trajeto de elucidação da reprodução social escravista.

Ao fim e ao cabo, o que a perspectiva da reprodução social demonstra- e pode auxiliar no entendimento de como todo o corpo do capitalismo se reproduziu em determinado momento deste sistema histórico - é que as categorias da economia política conforme elucidadas por Marx já são, por pressuposto, generificadas. Ao consultarmos a perspectiva do capitalismo racial, vemos que essas mesmas categorias são também racializadas. Esses pensadores defendem que, nesse sistema, a exploração e a racialização possuem a mesma natureza. Conforme aponta Burden-Stelly (2020, p. 3), a negritude é uma categoria do capitalismo para extração de mais-valia, sendo ao mesmo tempo uma "condição quinta-essencial de descartabilidade, dispensabilidade e desvalorização”.

Por esse prisma, afirma-se que entre os mecanismos de apropriação - de mais-valia - e expropriação - de meios de produção -, encontram-se a produção do estigma racial e do racismo, fundamentais para compreensão de como essas 
ações se realizaram na relação da escravidão com o desenvolvimento e andamento do sistema capitalista (Singh, 2017). Nele, enquanto os trabalhadores livres europeus eram expropriados de suas terras e tinham o valor de sua força de trabalho apropriadas pelos capitalistas, os trabalhadores negros eram apropriados como bens e, simultaneamente, expropriados de seus corpos com a escravizaçãoํ․ Isto é, o capitalismo dependeu da transformação de certos corpos - racializando-os em uma forma de capital humano (Singh, 2017).

Adentrando, a partir de agora, na discussão da reprodução social da escravidão pela realidade brasileira, a qual envolve, inescapavelmente, o embricamento entre o gênero e a raça para a reprodução social do capitalismo, atesta-se desde já que a instituição escravista foi mais do que uma forma de repor força de trabalho. Há de se salientar que a escravidão não foi um modo produtivo que só se reproduziu na base de renovação de trabalhadores forçosamente imigrados. Ela também se reproduziu de forma puramente endógena. A exemplo da escravidão negra brasileira: entre 1850 - com a promulgação da Lei Eusébio de Queirós que proibiu o tráfico internacional de escravos - e 1888, quando a instituição foi abolida, o modo produtivo escravista continuou em funcionamento. Desenvolveram-se meios de renovação da força de trabalho escrava não embasada na captação externa de trabalhadores. Para além do tráfico interno que se intensificou, já se sabe que a população de trabalhadores escravizados cresceu nesse período (Pessoa, 2017; Salles, 2008), o que indica que a reprodução biológica de escravizados no interior das plantations foi operante e intencionada. Combinados, foram eles suficientes como modo de realizar a reprodução social escravista por quase quatro décadas.

Isto posto, entende-se que a reposição exógena de trabalhadores não pode ser considerada o caráter específico da reprodução social escravista. Mas se não esse, qual?Não entendendo essa discussão como finalizada, o que se procurará discutir aqui é um caminho para essa resposta e até onde esse caminho nos leva. Primeiramente, se apresenta a interpretação da escravidão enquanto expressão capitalista e, depois, partimos para a inserção de um elemento empírico à discussão da reprodução social escravista: manuais de agricultura brasileiros.

Antes de mais, sublinha-se que a escravidão aqui em análise é a chamada moderna, negra ou racial, que se inicia nas Américas com a expansão do Ocidente. É sabido que a escravidão existia antes mesmo do fenômeno expansionista, como é o caso da escravidão romana e grega, em que havia pessoas escravizadas e

1 Tal afirmação é feita pelo historiador Tâmis Parronem debate promovido pela Revista Rosa, com o intuito de discutir a edição 2 do volume 2 da revista (2020) sobre capitalismo racial. 
tidas como posse. Porém, a moderna adequou-se à época de impérios marinhos e à emergência de um capitalismo mercantil. Nela, trabalhadores foram forçosamente retirados de um continente para trabalharem em colônias de um segundo continente e produzirem artigos de consumo e matéria-prima às metrópoles de um terceiro continente (Blackburn, 2016). Essa escravidão surgiu durante o processo de acumulação primitiva de capital e foi crucial para o desenvolvimento da indústria europeia, que se beneficiou das commodities tropicais bem como do capital obtido com o tráfico de escravizados (Marx, 2011 [1867]; Williams, 1975 [1944]). A instituição perseverou, se reformulou e se intensificou por décadas a fio mesmo depois de iniciada a Revolução Industrial (Tomich, 2011; Blackburn, 2016).

Pela ótica do sistema-mundo capitalista, a escravidão não só foi simultânea ao capitalismo, mas estava incorporada a ele. Immanuel Wallerstein (1974; 1979) afirma que, em alguns períodos do capitalismo histórico, o sistema-mundo capitalista agregava zonas de produção assalariada e outras de base coercitiva e semicoercitiva em sua arena econômica. Isso se deu nos primeiros quatro séculos da economia-mundo capitalista, que entra em seu estágio inicial no fim do século XIV e início do XV, quando três de seus pilares estruturais são fundados: (i) a expansão geográfica do mundo com a conquista das Américas, o que, por sua vez, (ii) possibilitou o desenvolvimento de distintos métodos de controle de trabalho para distintos produtos e zonas do globo, que se relacionavam comercialmente no mercado mundial a partir de um ordenamento imposto por (iii) aparelhos de Estados fortes e centralizados (Wallerstein, 1974).

Os territórios recém anexados eram a zona periférica dessa economia, onde se produziam commodities primárias e empregava-se o método de controle de trabalho escravo. Já os que compunham a zona central produziam mercadorias com alto valor agregado pelo método de controle de trabalho assalariado. Esses países e territórios consistiam no sistema-mundo capitalista, um sistema interestatal com economia codependente de relações de troca internacionais. Tais relações resultavam numa acumulação desigual de capital a favor dos países centrais, uma vez que possuíam maior domínio político e econômico sobre as cadeias de produção (Wallerstein, 1974) ${ }^{2}$.

2 Na América Latina, a perspectiva do sistema-mundo capitalista foi mais comumente desenvolvida pelos pensadores das teorias da dependência, que, grosso modo, atestam que os Estados latino-americanos com menor tecnologia e força produtiva surgem numa posição de subalternos aos países centrais na dinâmica de circulaçãoo internacional de capital. Assim, o desenvolvimento dos periféricos fica à mercê da demanda e, consequentemente, do desenvolvimento sempre mais avançado dos centrais. Quanto à escravidão na periferia, Marini (2000 [1973]) afirma que o modelo produtivo deixou de ser interessante aos proprietários rurais brasileiros em razão da mão de obra escrava se tornar, com o tempo, mais cara que a livre, já que a reprodução desses 
Neste cenário, o trabalho reprodutivo das mulheres para a continuidade da sociedade de classes capitalista assume uma função da maior relevância:

Se as crianças têm de nascer, são as mulheres que as carregam e dão à luz. As mulheres pertencentes à classe subalterna têm, portanto, um papel especial no que diz respeito à substituição geracional da força de trabalho. Embora também possam ser produtoras diretas, é em seu papel diferencial na reprodução da força de trabalho que está na raiz de sua opressão na sociedade de classes (Vogel, 2013 [1983], p. 150).

Com base no que atestam os dois referidos teóricos, pode-se afirmar que tanto as mulheres escravizadas periféricas como as mulheres livres centrais eram oprimidas para renovar a força de trabalho dos explorados neste sistema para fins de acumulação. Contudo, acredita-se que, em razão dos métodos de exploração serem distintos nas duas geografias, os métodos de opressão dessas mulheres para reproduzirem também seriam: se havia um processo de produção assalariado que continha ao mesmo tempo um modo de reprodução, onde se inseria a opressão das mulheres para a reprodução dos assalariados, há de ter um processo de produção escravista que continha ao mesmo tempo um modo de reprodução, onde se inseria a opressão das mulheres para a reprodução dos escravizados.

A especificidade do processo de produção escravista com enfoque nos explorados já foi estudada por Mintz (1978), que busca uma definição isolada de proletariado e escravizado baseando-se nas diferentes relações de exploração que igualmente intencionavam a acumulação de capital. Ora, diz ele, numa relação de

trabalhadores havia de ser custeada pelos senhores de escravos. Sobre a escravidão sulista brasileira, Cardoso (1977) afirma que os escravistas do século XIX agiam guiados por uma racionalidade paternalista e não capitalista, ou seja, optavam por reduzir a margem de lucro para, com isso, manter a mão de obra escrava. Apesar de não abordarem especificamente a escravidão do sul do Brasil, a tese da insensatez econômica da escravidão já foi contradita por algumas vertentes historiográficas da década de 1970 e mais atuais: pelos neoclássicos Fogel e Engerman (1974), por exemplo, que aplicam método da cliometria para atestar a racionalidade capitalista da escravidão; como também pela perspectiva da segunda escravidão, que percebe a escravidão oitocentista como profundamente moldada pela lógica da acumulação de capital. Marini (2000 [1973]), no entanto, ainda colabora com um importante debate à reprodução da escravidão. Diz ele que a periferia do sistema reduz o valor do trabalho mundial, porque por ter uma força de trabalho mais barata remete mercadorias de consumo a baixo custo ao mercado mundial, ocasionando uma descida do valor do trabalho socialmente necessário à reprodução do trabalhador industrial. Essa constatação pode ampliar a discussão proposta por esse artigo quando se insere a variante do racismo para o funcionamento do sistema, tendo em vista que esse opera para deflacionar o preço da força de trabalho mundial ao produzir trabalhadores mais baratos do que outros. Desse modo, entende-se que as mulheres escravizadas não só produziam os trabalhadores que eram mercadorias, mas as que também garantiam a redução do valor da força de trabalho mundial. 
trabalho estabelecida entre capitalista e trabalhador assalariado, o trabalhador possui e vende sua força de trabalho. Já o escravizado não vendia sua força de trabalho ao escravista porque não era um livre detentor dessa mercadoria, uma vez que ele próprio era uma mercadoria.

O trabalho do escravizado não é, na maioria das circunstâncias, uma mercadoria dentro da economia escravista, mas os produtos de seu trabalho são, na maioria das circunstâncias, mercadorias; eles mesmos parecem ser uma forma de capital, apesar de serem seres humanos (Mintz, 1978, p. 90).

Além de mercadoria e portadores de força de trabalho para ser empenhada na produção agrícola, os escravizados eram um bem contabilizado como patrimônio do senhor e, ainda mais valiosamente, um capital ativo acumulado, porque podiam ser utilizados como garantia de fiabilidade do proprietário rural para obter empréstimos (Blackburn, 2016). Evidencia-se assim o caráter racial da formação e ordenamento do capitalismo, que a partir da diferenciação racial criava valor com a superexploração do trabalho escravo e com a especulação financeira ocasionada pela garantia crediária materializada no corpo negro (Singh, 2017). Dessarte, pode-se já alegar que a mulher escravizada, quando gerava um portador de força de trabalho, gerava conjuntamente essas outras qualidades capazes de serem valoradas. Contudo, essa capacidade reprodutiva nem sempre foi valiosa para o modo produtivo escravista.

A reprodução endógena dos escravizados ganha protagonismo principalmente durante a segunda escravidão, quando os países e territórios escravistas tiveram de, em dado momento, extinguir o tráfico internacional de escravos. A segunda escravidão estendeu-se entre fins do século XVIII e do XIX, quando a instituição perdeu o caráter colonial e passou a operar numa relação de livre comércio com o norte industrial. Ela sobreviveu e acompanhou a Revolução Industrial, ganhando um caráter industrial e de escala. Consequentemente, o mercado mundial passou a demandar mais commodities tropicais, o que desencadeou ações escravistas mais racializadas, intensivas e extensivas (Tomich, 2011; Blackburn, 2016; 1988). Esse foi um fenômeno principalmente vivenciado por dois países e um território escravistas: Estados Unidos, Brasil e Cuba. Foram os que conseguiram harmonizar-se ao ritmo imposto pelo mercado mundial e, também, fazer frente à hostilidade da instituição da época oitocentista, reconhecida como o século antiescravista (Tomich, 2011, Blackburn, 2016; Marquese, Parron, 2011). 
Por isso, a escravidão oitocentista no Brasil tem incontornável realce quando se busca perceber a sua reprodução social, pois abarcou uma ameaça à continuidade da instituição: a reposição da força de trabalho escrava. Em razão das investidas diplomáticas contrárias à escravidão, sobretudo por parte da Inglaterra, o Brasil cedia à extinção do tráfico internacional de escravos ou punha-se sob o risco de perder a sua soberania (Tomich, 2011; Marquese, Parron, 2011). As consequências das disputas diplomáticas transparecem nas práticas recomendadas à reprodução da escravidão e da escravaria descritas nos manuais. Eles serão, agora, observados no intuito de encontrar o caráter específico da reprodução social escravista.

\section{ENTRE O PRODUTIVO E O REPRODUTIVO: AS PRÁTICAS ESCRAVISTAS PARA A REPRODUÇÃO DO CAPITAL}

Serão quatro manuais de agricultura analisados, escritos ao longo do século XIX por proprietários rurais escravistas, a saber: "O Manual do Agricultor Brasileiro”, de Augusto Taunay (1839); "Memoria sobre a Fundação de huma Fazenda na Provincia do Rio de Janeiro", de Francisco Peixoto de Lacerda Vernek (1847); "Idéas sobre colonisação precedidas de uma succinta exposição dos principios geraes que regem a população", de Luís Peixoto de Lacerda Werneck (1855); e "Manual do Agricultor de Generos Alimenticios”, de Padre Antonio Caetano da Fonseca (1863).

Essas obras são como um guia normatizador das práticas escravistas oitocentistas, já que seus escritos se baseiam "em concepções formuladas em redes de conhecimento historicamente distintas e pretendem intervir em contextos materiais específicos, isto é, buscaram responder aos problemas das sociedades escravistas a que pertenciam seus autores" (Marquese, 2004, p. 12). Informa-se que esses autores são planters do Vale do Paraíba, região produtora de café no século XIX. Neste século, o grão virou o principal produto de exportação do país ao passo que se tornava um artigo de consumo de massa, disseminado entre uma classe média e urbana emergente dos países em industrialização (Marquese, Salles, 2016).

Desses manuais, dois foram escritos antes da proibição do tráfico internacional. Nesta primeira fase, a substituição dos escravizados era executada majoritariamente por meio da compra de trabalhadores oriundos do continente africano. Os outros dois manuais foram escritos quando o tráfico transatlântico já estava extinto, e a reposição se dava na base do tráfico interprovinciano e da procriação da escravaria interna às plantations (Salles, Marquese, 2016; Salles, 2008; Marquese, 2008).

Os dois primeiros manuais, portanto, formulam práticas escravistas quando a substituição dos trabalhadores era feita de modo exógeno. Eles mostram como 
essa tipicidade moldava a racionalidade dos senhores escravistas que agiam para se obter lucro com a exploração do trabalho escravo. Escrito em 1839, o manual de Taunay carrega várias passagens em que o trabalhador escravizado nas plantations brasileiras é referenciado como o adquirido, bem como expõem como alcançar a reprodução de capital:

Os pretos não se compram para se ter o gosto de os sustentar e de os ver folgar, mas sim para tirar do seu trabalho os meios de subsistir e lucrar. O salário deste trabalho foi pago em parte por uma vez pelo dinheiro da compra, e a outra parte paga-se diariamente com o sustento (Taunay, [1839] 2001, p. 64).

Em Marx (2011 [1867]), o processo de obtenção de capital advém da relação entre mais-trabalho e trabalho socialmente necessário. O trabalhador recebe em troca de seu tempo de execução de força de trabalho para a cristalização de mercadorias apenas o valor do trabalho socialmente necessário à sua reprodução e a dos seus. O restante do valor de seu trabalho - a parte não paga pelo mais-trabalho - é apropriada pelo capitalista, o que leva o nome de mais-valia. Ainda, o valor do trabalho socialmente necessário pago ao trabalhador para a sua reprodução é contabilizado, na análise de Marx, como aquele suficiente para suprir as demandas do trabalhador com compra de mercadorias essenciais à sua subsistência.

Agora, se observarmos o trecho acima, vemos como o escravista realizava essa contabilidade. Taunay entende a compra do escravizado somada ao provimento da sua subsistência como o valor pago pelo trabalho socialmente necessário à reprodução do trabalhador. O senhor de escravos obtinha o lucro com a diferença entre o que foi recebido com a venda das mercadorias para exportação e o que foi gasto para a compra e a reprodução do trabalhador. Nessa passagem, está turvo quem executava o trabalho necessário à reprodução dos trabalhadores, o que Vogel (2013 [1983]) pôs em destaque quando analisou esse conceito. Contudo, os manuais seguintes expõem que o trabalho de provimento da vida - alimentação, roupas, cuidados etc. - era executado por escravizados que estavam fora da produção agrícola direta, como amas, crianças e idosos.

Há ainda um outro fator para o cálculo quando o trabalho é escravo: a morte. Essa variante é abordada principalmente por Vernek (1847), que publica seu manual já numa conjuntura de intensa disputa pela continuidade da instituição escravista brasileira. Havia dois anos que a Inglaterra tinha promulgado a Bill Aberdeen, permitindo que a marinha inglesa apreendesse navios negreiros no oceano Atlântico. Como efeito, o preço dos escravizados inflacionou e o acesso ao 
mercado de trabalho escravo foi comprometido. Diz ele: "Vê-se a necessidade de continuar com esse cancro roedor, cujo preço actual não está em harmonia com a renda que d'elle se póde tirar; inda de mais accresce a immensa mortandade a que estão sujeitos e que devora fortunas colossais [...]"(Vernek, 1847, p. 16).

No excerto, percebemos a crítica do autor à escravidão dada a capacidade reduzida do modo em prover maiores lucros aos senhores escravistas, já que o alto preço do escravizado reduzia o retorno obtido com a exploração do seu trabalho. A morte era um problema porque demandava o dispêndio de recursos na reposição do portador de força de trabalho, já considerado caro para um curto período de vida produtiva. Assim, em Vernek, a mortalidade assume uma presença central na razão econômica para fins lucrativos do senhor, julgando preciso aumentar as estratégias de manutenção de salubridade da escravaria: "É de se esperar que a alta do preço dos negros e menores rendimentos da agricultura tornem os senhores mais solícitos no tratamento de sua escravatura” (Vernek, 1847, p. 64).

Em síntese, essas passagens demonstram que a reprodução da força de trabalho escrava era da alçada de interesse da classe senhorial, que desenvolvia estratégias para garanti-la de forma que obtivessem as melhores chances de acumulação. Assim, já se indica que esse processo de reprodução foi formatado pelo caráter específico da relação social de produção escravista, mas é preciso ainda chegar na origem da sua especificidade relativa à reprodução.

Dá-se seguimento, agora, à mudança mais brusca no processo de reprodução da escravidão dentro do mesmo modo produtivo escravista: quando o processo passou a ser endógeno, apoiado no tráfico interno e procriação da escravaria. Por esse período ter sido extenso, crê-se que o tráfico interno seria insuficiente para repor a força de trabalho escravizada despendida nas plantations se não fosse ela mesma renovada. Cabe ainda reforçar que, nesse período, mesmo se a renovação dos escravizados em algumas plantations fosse realizada pela compra, a reprodução biológica desses trabalhadores havia de ser feita endogenamente, fronteira adentro do Brasil Império.

No manual de Luís Werneck (1865 [1855]), filho de Francisco Vernek, há uma explícita defesa da reprodução biológica dos escravizados como único meio de se manter a economia exportadora do país. O filho advoga pelo crescimento populacional brasileiro, porque entende que o desenvolvimento econômico do Brasil dependia da disponibilização de uma grande população laboriosa. Frisa-se que ele defende a escravidão como meio de desenvolver o país ao ponto de possibilitar a inserção de colônias agrícolas de viveres, onde se empregaria colonos europeus. 
O autor escravista diz que "independente da colonização [imigração africana], nós poderíamos só pela acção procreativa da especie humana levar a um transbordamento de população, em poucos annos, esse nucleo de população conterranea, ora existente no paiz" (Werneck, 1865 [1855], p. 12). É curioso porque evidencia-se em seu manual a preocupação única com a multiplicação da classe subordinada, a composta pelo contingente de escravizados. Confirma-se, desse modo, o postulado de Vogel (2013 [1983]) de que, na sociedade de classes capitalista, a reprodução da força de trabalho consiste na reprodução daqueles que estão sob o jugo da exploração.

Para ocasionar o crescimento populacional, o autor se apoia no exemplo dos Estados Unidos e nas estratégias adotadas pelos planters de lá, que, segundo ele, tinham o intuito tanto de reproduzir escravizados para suas plantations como para os destinar enquanto mercadorias ao tráfico interno. $\mathrm{O}$ autor prefigura essa realidade à brasileira ao refletir sobre o custo do escravizado, ponderando que tal valor só reduziria se houvesse avultada reprodução natural.

Os escravos devem encarecer com o augmento da população livre, e da riqueza publica e privada. Como todas as mercadorias, à proporção que se augmentam os consumidores, que crescer a cuncurrencia, o escravo subirá de preço, a menos que não haja uma prodigiosa multiplicação delles pela procriação, e um estado estacionario na marcha do incremento da população livre, e da riqueza nacional (Werneck, 1865 [1855], p. 53-4).

No excerto, o autor afirma que só se bem ofertada a mão de obra escrava se manteria mais barata do que a livre. Em cenário de escassez de escravizados, a oferta não supriria a demanda dos "consumidores", os proprietários rurais. O autor entende ambos trabalhadores como mercadorias e que, igualmente, provocam um dispêndio de recursos financeiros daquele que se beneficia da exploração de seu trabalho. Sendo mercadorias, o contingente de trabalhadores mais numeroso teria a força de trabalho mais barata e seria mais empregada do que a mais cara, essa é a "concorrência”. Os escravizados se tornariam mais baratos no mercado de trabalho - onde estariam disponibilizados tanto trabalhadores escravizados como livres - à medida que a procriação deles aumentasse.

Então, Werneck vê o trabalhador escravizado e o trabalhador livre como mercadorias similares. Porém, sabe-se que o trabalhador livre não é uma mercadoria, ele tem inatamente uma possível mercadoria chamada força de trabalho. Já o escravizado é uma mercadoria e, ao ser comprado, passa a dever essa força de 
trabalho por tempo indeterminado ao proprietário rural (Mintz, 1978; Johnson, 2004). Só com esse entendimento, de que se comprava mercadorias distintas para o mesmo fim - o emprego da força de trabalho na produção agrícola -, é que o raciocínio de Werneck faz sentido e responde, a certa medida, à lógica de funcionamento do mercado de força de trabalho:

A economia nacional considera o trabalho abstratamente como uma coisa; o trabalho é uma mercadoria: se o preço é alto, a mercadoria é muito procurada; se é baixo, [a mercadoria] é muito oferecida; como mercadoria, o trabalho deve baixar cada vez mais de preço: o que força a isso é em parte a concorrência entre capitalista e trabalhador, em parte a concorrência entre trabalhadores (Marx, 2004 [1844], p. 35-6).

Não se pode dizer que havia concorrência entre escravizados. Relembra-se que tais trabalhadores sofreram um processo de desumanização, em que eram despossuídos de si mesmos e, com isso, transformados em bens .O processo de mercantilização de corpos alicerçava-se sobre a raça no capitalismo. Essa concepção de raça, que distinguia os corpos negros como naturalmente inferiores e comodificáveis, é constituída sobre as mesmas estruturas elementares que transformou terra, trabalho e dinheiro em mercadorias e permitiu que o capitalismo viesse à luz do dia (Wolfe apud Singh, 2017). Isto é, o capitalismo dominava e se expandia sobre a apropriação da terra, sobre a apropriação do mais-trabalho do trabalhador branco e livre e sobre a apropriação do corpo negro, convertendo-os em formas de capital. Consequentemente, os escravizados não tinham qualquer autonomia sobre sua força de trabalho para vendê-la a um preço reduzido, tampouco reduziria o seu próprio preço para ser escravizado numa determinada plantation; ele era uma mercadoria desde a retirada de seu local originário. Sem propriamente incorrer numa disputa, a concorrência seria apenas entre o escravizado e o livre, e a citação de Werneck indica uma semelhança entre os modos: o custo do trabalhador, no caso do escravizado, e do trabalho, no caso do trabalhador livre, se relacionava com o custo da reprodução da força de trabalho.

Podemos começar a pensar o custo da reprodução da força de trabalho escrava por uma ponderação já realizada: ao gerar um bebê, a mulher escravizada estava gerando uma futura mercadoria ao seu proprietário, bem como um bem que desempenhava vários papeis no processo de acumulação do senhor escravista. Disso se percebe que as atividades executadas para gerar e regenerar o trabalhador eram um trabalho reprodutivo de cariz produtivo, isto é, produzia valor ao capital. Portanto, 
enquanto no método de controle de trabalho assalariado as esferas produtivas e reprodutivas são separadas em (i) a que produz valor de troca e (ii) a que produz valor de uso, no método de controle de trabalho escravo essa fronteira é volúvel: as esferas de produção e reprodução são diluídas numa só. Tal aspecto prenuncia ser um elemento fundamental do caráter específico da reprodução social escravista.

Tendo em vista que a produção do escravizado tinha um custo, aprofundemos a constatação ao abordar os tipos de consumo em Marx (2011 [1867]): produtivo e individual. O primeiro é o consumo executado pelo capitalista com meios de produção, em que se insere o consumo da força de trabalho - o pagamento ao trabalhador. O consumo produtivo é de encargo do capitalista, que terá posse da mercadoria final produzida, cuja venda garante a obtenção do lucro. Deste modo, o capitalista não tem qualquer prejuízo em custear o consumo produtivo, contanto que a mercadoria produzida seja vendida ao menos pelo custo de produção. Já o segundo diz respeito ao consumo das pessoas para garantir a sua subsistência. É um consumo que podemos chamar de reprodutivo, o qual o trabalhador realiza para que tenha condições de vender novamente a sua força de trabalho. Comprando as mercadorias necessárias à sua reprodução e a dos seus, esse consumo faz parte do processo de reprodução de capital do capitalista.

Ele lucra não apenas com o que recebe do trabalhador, mas também com o que lhe dá. O capital que foi alienado em troca da força de trabalho é convertido em meios de subsistência, cujo consumo serve para reproduzir os músculos, os nervos, os ossos, o cérebro dos trabalhadores existentes e para produzir novos trabalhadores [...]. Tal consumo é produção e reprodução do meio de produção mais indispensável ao capitalista: o próprio trabalhador (Marx, 2011 [1867], p. 788)

Se pensarmos a escravidão à luz do consumo produtivo e individual tais diferenças não são assim identificadas. O consumo produtivo do escravista também envolvia o custeio dos meios necessários à produção da mercadoria final, por exemplo, o café remetido ao mercado mundial. Mas entre esses meios, se encontra o trabalhador escravizado, que tinha os dispêndios da sua reprodução - consumo individual - como um custo do proprietário rural. Ou seja, o consumo reprodutivo do trabalhador era consumo produtivo do escravista. Por meio dessa junção de esferas produtivas e reprodutivas, em que se misturam os recursos do capitalista nos consumos necessários para o processo de produção, vê-se também o caráter único e complexo da reprodução social da escravidão. 
Os manuais mostram que, na equação do lucro senhorial, o custo do consumo produtivo do escravista havia de ser menor que o valor das mercadorias finais. Enquanto os trabalhadores vinham das arenas externas e eram comprados por um preço baixo no mercado de trabalho, o somatório de sua compra mais a de sua reprodução era tida como vantajosa pelos proprietários rurais, como visto em Taunay (2001 [1839]). A partir do momento que o custo da compra do trabalhador fica muito alto, somando-se o custeio da sua reprodução, o lucro não era alcançado com a mesma facilidade. Portanto, os autores escravistas equacionam fatores que os capitalistas de modo assalariado não calculavam à luz da reprodução dos trabalhadores e da reprodução do capital.

Por exemplo, na morte de um trabalhador assalariado, o capitalista tem de recorrer ao mercado de trabalho para comprar força de trabalho de um novo trabalhador, sem aumentar a previsão do seu consumo produtivo. No caso do capitalista escravista, enquanto havia tráfico internacional de escravos, a morte do trabalhador significava maior empenho de recursos para consumo produtivo. Mas, quando o tráfico internacional foi proibido, a compra de um trabalhador não era garantida para retorno lucrativo. Se a plantation não reproduzisse seus próprios escravizados até a idade produtiva no ritmo que os trabalhadores morriam, o escravista corria o risco de reduzir a sua força produtiva ou dispor excessivamente do seu capital acumulado em novas compras.

Portanto, não é ao acaso que os manuais da segunda fase da escravidão dão atenção redobrada à procriação dos escravos, e não às compras. A procriação era, afinal, uma produção de mercadoria que evitaria um consumo produtivo excessivo. Contudo, a reprodução biológica dos escravizados abarcava o custeio da criação por anos antes de se obter retorno. Mas, conforme garantiu Fonseca (1863), se realizada seguindo as recomendações apresentadas à frente, o escravista poderia lucrar com a reprodução.

\section{CONTROLE DO CORPO: A MULHER ESCRAVIZADA COMO REPRODUTORA DE FORÇA DE TRABALHO}

Quanto aos manuais da primeira fase, pode-se dizer que a procriação não era um assunto da maior importância, tendo em vista que o tráfico de escravos ainda era operante, via que também se mostrava economicamente mais favorável. Como tráfico internacional legal no Brasil, era mais barato comprar um escravizado já em idade produtiva do que criar um bebê até a idade aconselhada à produção agrícola (Wallerstein, 1979). Pensamento similar aparece em Vogel (2013 [1983]), quando a autora diz que, para além de um ritmo mortal de trabalho 
escravo impeditivo de realizar uma reprodução biológica na demanda necessária, a gravidez e a lactação declinam a capacidade produtiva da trabalhadora, tendo essa mulher de ser mantida pelo proprietário rural mesmo afastada da produção direta de mercadorias. Logo, a reprodução biológica de escravizados nem sempre representava um benefício econômico ao proprietário rural. A procriação dos trabalhadores poderia inclusive resultar num investimento perdido: a prole podia morrer antes de atingir a idade produtiva, às vistas da elevada taxa de mortalidade infantil dos escravizados.

Sobre a insuficiência da reprodução biológica interna às plantations, Taunay diz: "A América devora os pretos: se a contínua importação não os recrutasse, em breve a raça desapareceria entre nós" (2001 [1839], p. 76). Seguidamente, ele faz observações sobre a relação entre os sexos e à procriação, aconselhando equiparar "o número dos machos aos das fêmeas", pois assim o senhor de escravos "pode contar que com bem poucas compras conservará a sua escravatura” (Taunay, 2001 [1839], p. 78). Como já se assinala, o autor demonstra ter na reprodução biológica da escravaria algo natural e inevitável, sem precisar da imposição dos senhores: “[...] para conseguir bastará não contrariar a natureza que convida os sexos a se reunirem" (Taunay, 2001 [1839], p. 78).

Retomando a teoria da reprodução social, a ideia de que a procriação é algo puramente natural é falaciosa e os manuais deixam isso muito claro, apesar das afirmações contrárias dos autores. As práticas normatizadas mostram formas de manipular a procriação da escravaria. Tanto é assim que Taunay (2001 [1839]) descreve o modo pelo qual julga melhor regular a vida dos casais e a criação de bebês e crianças. Ele diz que as mulheres grávidas devem ter trabalhos moderados e demandam maior atenção para o parto e amamentação; que as crianças são frágeis e que a infância necessita de mais cuidados; e que os casais, mesmo se casados, devem viver em ranchos separados por sexo e se encontrar somente à noite, quando findado o turno de trabalho.

Já o autor do manual seguinte, Vernek (1847), aconselhava que os casais vivessem juntos com seus filhos num só rancho. Esse autor é ainda mais sucinto no que trata da reprodução biológica dos escravizados. Suas recomendações levam a uma maior autonomia da família escrava, a quem aconselha que seja concedida um pedaço de terra para próprio cultivo, além da habitação familiar na senzala. Isto é, vê-se maior incentivo à constituição da família escrava. Particularmente à procriação, diz: 
Não mandeis a preta que estiver criando à roça por espaço de humanno, occupai-a em serviço de casa, como, lavar roupa, escolher café, e outros objectos. Quando ella tiver seu filho criado irá então, deixando o pequeno entregue a huma outra que deve ser a ama secca de todos, para os lavar, mudar a roupa, e dar-lhe a sua comida (Vernek, 1847, p. 17).

Na comparação entre os dois autores dessa primeira fase da escravidão oitocentista brasileira, percebemos uma variabilidade nas estratégias para a renovação e reposição da força de trabalho escrava. Pela normatização dessas práticas, vê-se que mesmo com a renovação geracional dos trabalhadores sendo realizada majoritariamente de modo exógeno, ainda assim havia discrepâncias sobre como se devia agir para obter a reprodução social da escravidão, as quais variavam com a conjuntura sócio-histórica em que tais ações se manifestaram. Fica claro que, dentro de um processo de reprodução nada é universal, tampouco fixo, mesmo quando o modo de produção se mantém.

Quanto aos autores da segunda fase, notou-se que Werneck foca mais numa argumentação pelo crescimento vegetativo dos escravizados e menos no método para se ocasionar o desejado. Segundo ele, para aumentar a população escravizada existente no país bastaria "a solicitude pela gravidez, mais zelo e cuidado para com os recem-nascidos e as crianças” (Werneck, 1865[1855], p. 23).

Já Fonseca (1963) vai ao pormenor de como promover a procriação, embasando argumentos no lucro do senhor e na humanidade do escravizado. Lembra-se que quando da publicação deste manual, os Estados Unidos estavam mergulhados na Guerra de Secessão, e a instituição como um todo enfrentava uma crise com insurgências escravas mais frequentes e com o crescimento de movimentos abolicionistas, inclusive dentro do Império brasileiro (Salles, 2008). Diz o escravista:

Portanto devem lembrar-se os fazendeiros, que os seus escravos também são homens, e tem como eles a mesma propensão para o amor, e por isso lhes devem facultar casarem-se à sua vontade, pois d'ahi provêm socego e moralidade dos escravos, assim como o lucro e tranquilidade dos senhores, como vou expor.[...] Além de tudo isto, a prole enriquece a seu senhor (Fonseca, 1863, p. 102).

$\mathrm{O}$ autor argumenta em favor do casamento entre os escravizados amparando-se no lucro gerado pela procriação, sem especificar se esse lucro advém da exploração da força de trabalho futura ou da venda do escravizado. Fonseca demonstra-se mais interessado em explanar como provocar a reprodução bioló- 
gica da escravaria do que no porquê. Descreve a criação dos escravizados como um investimento do proprietário rural em mercadorias meio de produção para, depois, obter retorno financeiro.

Quando os meninos passarem de cinco annos, devem ir aprendendo alguma doutrina christã, e principiar a trabalhar em serviços que forem compativeis com as suas forças, porém por pouco tempo: pois é isto somente para moralisa-los, e para desenvolver e fortificar os seus musculos, e não para tirar fructo do seu trabalho; pois só de dez annos por diante podem dar algum serviço a seus senhores (Fonseca, 1863, p. 101).

Quanto às mulheres, é especialmente detalhista. É o primeiro autor a qualificar a mulher escravizada, independente da condição de gestante ou lactante, como mais frágil do que o homem escravizado: "As pretas regulão o mesmo tratamento [de alimentação]; mas o seu serviço deve ser menos pesado, pois a sua condição é mais débil" (Fonseca, 1863, p. 98). Dessarte, o autor indica que há, no período em que a reprodução da escravidão passou a depender do corpo da mulher, uma alteração da ideologia sobre os gêneros: a escravizada começou a ser caracterizada como naturalmente mais frágil.

Sabe-se que, à exceção das que estavam alocadas nas casas-grandes e como amas secas, as escravizadas participavam tanto quanto os homens da produção agrícola. Mas, a obra de Fonseca indica que houve uma alteração do esperado em relação à produtividade do trabalho feminino quando a capacidade reprodutiva de seu corpo entrou na contabilidade positiva do modo escravista ${ }^{3}$. Deriva-se dessa nova percepção uma especial preocupação do autor com o ciclo reprodutivo das trabalhadoras.

As mulheres no tempo de sua regra, não devem pisar na lama nem metter os pés dentro d'agua fria, porque isto pode causar sua suppressão e graves enfermidades. As pretas neste tempo, e no da sua gravidez, não devem ser tratadas com rigor; porque isto muitas vezes é causa dos abortos, suppressão das regras, e de muitos outros inconvenientes (Fonseca, 1863, p. 98)

3 Essa temática é abordada por Rhoda Reddock (1984 apud Mies, 2014) que ao estudar a escravidão colonial e pós-colonial no Caribe constatou que, durante a vigência do tráfico internacional, os escravistas orientavam-se por uma ideologia de gênero às escravizadas oposta a que os orientava na relação com suas mulheres. Diz ela que, nesse período, as escravizadas eram desencorajadas e até proibidas de casar e de gestar, uma vez que era mais barato comprar trabalhadores do que gerá-los. 
Nesse manual, é nítido que a prática escravista específica à mulher ansiava 0 futuro retorno financeiro obtido com a prole. Contudo, pondera-se ainda que, além de as escravizadas possibilitarem a produção de novos trabalhadores, também representavam o poder de continuidade da instituição escravista. A capacidade reprodutiva da mulher indicava a oportunidade de reproduzir uma raça tida como inferior e, assim, sujeita à escravidão (Morgan, 2004). Isto é, a reprodução biológica e geracional dos escravizados sofria de uma intenção para a manutenção da sociedade de classes brasileira, formada por proprietários rurais capitalistas brancos e negros escravizados. Portanto, a reprodução biológica, além de produzir trabalhadores, produzia a diferença fenotípica que alicerçava essa divisão social.

Antes de precisarem de seus corpos para a reprodução do modo escravista, já significavam a escravizada pelo útero. Isso é o que se vê, por exemplo, numa passagem do manual de Taunay, que entende que um filho de uma escravizada vai ser sempre escravizado, o que simbolizava a continuidade da instituição.

A escravidão dos crioulos é mais difícil de justificar do que a dos pais comprados na Costa. O filho segue a mãe, filius ventris sequitur; esta máxima do direito baseia-se na precisão que o parto tem para viver do leite da mãe, e do pão do senhor desta. A lei considera que o senhor não trataria da cria e não faria desembolsos durante a longa duração da infância, se não tivesse em perspectiva o trabalho do resto da vida (Taunay, 2001 [1839], p. 78).

Jennifer Morgan (2004), que investigou a relação entre reprodução de escravos e a experiência de vida das mulheres negras nas colônias inglesas do século XVIII, quando o tráfico internacional de escravos provia ao território, diz que a escravizada na plantation era tida num duplo sentido: para a execução do trabalho físico produtivo e pelo valor simbólico que dava sentido à escravidão racial. Então, mesmo se sobre as mulheres não houvesse qualquer interesse de parirem a próxima geração de escravizados, seus corpos eram revestidos pela simbologia da perpetuidade da escravidão, porque eram eles que transmitiam a condição racial. Com o tráfico internacional ativo e em um cenário escravista de altos índices de mortalidade infantil, o valor simbólico reprodutivo da mulher mantinha-se especulativo.

A vida das mulheres sob a escravidão nas Américas sempre incluiu as possibilidades de seus úteros. Quer trabalhassem entre cana-de-açúcar, arbustos de café, ou arrozais, os cálculos de custo-benefício dos senhores de escravos incluíam o valor especulativo de uma reprodução de força de trabalho (Morgan, 2004, p. 103). 
Neste ponto, ainda pode ser acrescido o pensamento de Lélia Gonzalez. Amparada em Décio Freitas (apud Gonzalez, 2020, po. 798), diz que os trabalhadores escravizados em regime de plantation podiam ser divididos em duas categorias: produtivos e não produtivos. Os produtivos estavam envolvidos diretamente nas atividades do cultivo agrícola e os não produtivos eram os prestadores de serviço, como feitores e criados. No caso das mulheres, empregavam-se como trabalhadoras do eito - produtivas - ou escravizadas mucamas - as criadas não produtivas das casas-grandes. No entanto, dentro da lógica escravista extensiva e intensiva de trabalho não pago e independente da função que exercia para o funcionamento das fazendas e da economia escravista, o fato de ser mulher racializada produzia efeitos violentos sobre ela por estar sob o jugo de uma superexploração econômico-sexual (Gonzalez, 2020, po 939). A autora indica que ser negra não era visto como um fator étnico, mas sim associado à sua capacidade produtiva e reprodutiva para a economia.

Assim, suscita-se a ideia de que independente de suas funções, as mulheres escravizadas carregavam o fardo de serem trabalhadoras produtivas ou improdutivas com a capacidade reprodutiva de gerar trabalhadores comoditizados, ou seja, de sempre serem uma força produtiva da reprodução dentro das plantations. Conforme aponta Gonzalez (2020, po. 843-974), por ser negra, a mulher trabalhadora sofria de uma manipulação sexual entendida como parte de seu trabalho e de sua condição de escravizada. Todas as suas ações abrangidas pela relação social de produção daquela economia escravista, se produtivas, reprodutivas ou improdutivas, eram economicamente sexuadas: o sexo, o desejo dos brancos sobre o seu corpo, a violação de seus corpos, as suas relações familiares etc. eram formatados para e pela produção de valor.

Entende-se, pelas teóricas abordadas e à luz dos manuais, que o controle sobre o corpo reprodutivo da mulher escravizada era exercido de modo que melhor respondesse aos interesses do processo de acumulação de capital. Se a preferência do proprietário rural era manter a mulher na produção agrícola direta e efetuar a reposição da força de trabalho pela compra, as práticas de dominação sobre ela seriam uma, orientadas pela rejeição da reprodução biológica; se a preferência fosse reproduzir endogenamente a próxima geração de portadores de força de trabalho, as práticas de dominação sobre a mulher seriam outra, orientadas pela promoção da reprodução biológica. De qualquer uma das formas, a experiência da mulher com o trabalho e a vida de escravizada era moldada em razão da funcionalidade atribuída a ela e de como iria participar no processo de acumulação de capital iniciado num contexto de produção específico, o escravista. 


\section{CONSIDERAÇÕES FINAIS}

Não seria uma novidade se esse artigo afirmasse que a escravidão acabou não porque era incompatível com o capitalismo, mas porque deixou de ter uma arena externa de onde angariar trabalhadores escravizados; essa constatação foi feita por Wallerstein (1979, p. 216). Tampouco que, como o capitalista arcava com a manutenção do escravizado, o trabalho escravo podia se tornar mais caro que $o$ livre, o que foi feito por Marini (2000 [1973]).

Sem entrar no debate se a reposição de mão de obra escrava foi, de fato, o que levou ao fim da instituição, o que as afirmações dos referidos teóricos apontam é que o processo de reprodução social escravista desempenhou papel central na crise da escravidão oitocentista. A partir da análise dos manuais de agricultura, o que esse artigo procurou demonstrar foi o porquê disso ocorrer. As análises obtidas indicam que a dimensão desse processo na crise do modelo escravista pode estar assente numa especificidade contida na reprodução social da escravidão. Nele, as esferas da produção e da reprodução demonstram estar unidas numa só.

Ainda assim, há de cautelar que essa conclusão é plausível e coerente com os autores agora referenciados ao se observar a escravidão oitocentista do Brasil por meio dos manuais escravistas brasileiros, tendo em vista que a escravidão, noutros países e territórios, tinha características peculiares ao contexto social e geográfico em que se estabelecia a relação social de produção escravista.

Por fim, viu-se que por estar inserida num específico método de controle de trabalho, a opressão da mulher que reproduzia trabalhadores para essa forma de exploração também tinha características peculiares, em que se articulavam à racialização necessária à operacionalização do controle de trabalho escravo e a generificação necessária à reprodução desse mesmo método. Assim, argumenta-se que tentar entender a reprodução social da escravidão importa à teoria social porque possibilita percebera manipulação de diferenças que tomaram formas próprias sob o capitalismo, como a raça e o gênero, para o cumprimento de seu objetivo: acumular capital.

\section{BIBLIOGRAFIA}

ARRUZZA, Cinzia (2010). Feminismo e Marxismo: entre casamentos e divórcios. Lisboa: Edições Combate.

BHATTACHARYA, Thiti (2019). O que é a teoria da reprodução social? Revista Outubro, n. 32, p. 99-113.

BLACKBURN, Robin (1988). The overthrow of Colonial Slavery 1776-1848. Londres/ Nova York: Verso. 
BLACKBURN, Robin (2016). “Por que segunda escravidão?” In: MARQUESE, Rafael; SALLES, Ricardo (Orgs). Escravidão e capitalismo histórico no século XIX: Cuba, Brasil e Estados Unidos. Rio de Janeiro: Civilização Brasileira.

BURDEN-STELLY, Charisse (2020). Modern U.S. Racial Capitalism: some theoretical insights. Monthly Review. Disponível em: https://monthlyreview.org/2020/o7/o1/ modern-u-s-racial-capitalism/ (acesso em 07/12/2021).

CARDOSO, Fernando Henrique (1977). Capitalismo e escravidão no Brasil meridional: o negro na sociedade escravocrata do Rio Grande do Sul. Rio de Janeiro: Paz e Terra.

CURCIO, Anna (2020). Marxist Feminism of Rupture. Disponível em: https://viewpointmag. com/2020/01/14/marxist-feminism-of-rupture/ (acesso em 07/12/2021).

FERGUSON, Susan; MCNALLY, David (2017). Capital, força de trabalho e relações de gênero. Revista Outubro, n. 29, p. 25-59.

FOGEL, Robert; ENGERMAN, Stanley (1974). Time on the Cross. The Economics of American Slavery. Boston: Little, Brown and Company.

FONSECA, Antonio Caetano (1863). Manual do agricultor dos generos alimenticios, ou methodo da cultura mixta destes generos nas terras cansadas pelo systema vegetoanimal; modo de criar e tratar o gado; e um pequeno tratado de medicina domestica para os fazendeiros, seguido de uma exposição sobre a cultura do algodão herbaceo. Rio de Janeiro: Eduardo \& Henrique Laemmert.

GONZALEZ, Lélia. "A mulher negra na sociedade brasileira: uma abordagem político-econômica”. In: RIOS, Flávia; LIMA, Márcia (Orgs). Por um feminismo afro-latino-americano: ensaios, intervenções e diálogos. Rio de Janeiro, Zahar, 2020 (e-book), po. 747-1095..

JOHNSON, Walter (2004). The Pedestal and the Veil: Rethinking the Capitalism/Slavery Question. Journal of the Early Republic, v. 24, n. 2, p. 299-308.

MARINI, Rui Mauro (2000 [1973]). Dialética da Dependência: uma antologia da obra de Rui Mauro Marini. Petrópolis: Editora Vozes; Buenos Aires: Clacso.

MARQUESE, Rafael (2004). Feitores do corpo, missionários da mente: Senhores, letrados e o controle dos escravos nas Américas, 166o-186o. São Paulo: Companhia das Letras.

MARQUESE, Rafael (2008). Diáspora africana, escravidão e paisagem da cafeicultura no Vale do Paraíba oitocentista. Almanack Braziliense, São Paulo, v. 7, p. 138-52.

MARQUESE, Rafael; SALLES, Ricardo (2016). Escravidão e capitalismo histórico no século XIX: Cuba, Brasil e Estados Unidos. Rio de Janeiro: Civilização Brasileira.

MARQUESE; RAFAEL; PARRON, Tâmis (2011). Internacional escravista: a política da Segunda Escravidão. Topoi, v. 12, n.23, p. 97-117.

MARX, Karl (2011 [1867]). O Capital: crítica da economia política. São Paulo: Boitempo. MARX, Karl (2004 [1844]). Manuscritos econômico-filosóficos. São Paulo: Boitempo. 
MIES, Maria (2014 [1986]). Patriarchy and Accumulation on a World Scale: Women in the international division of labour. Londres: Zed Books.

MINTZ, Sidney (1978). Was the plantation slave a proletarian? Review, v. 2, n. 1, p. 81-98. MORGAN, Jennifer (2004). Laboring women: reproduction and gender in the New World slavery. Pensilvânia: University of Pennsylvania Press.

PESSOA, Thiago (2017). "E depois da "Lei Eusébio"? Reprodução da escravidão e seus limites em um complexo de fazendas do vale do café (Rio de Janeiro, c. 1864-1888). Topoi, v. 18, n. 36, p. 465-89.

ROSA, Revista (2020). A questão racial no Brasil em perspectiva histórica. Rodas da Rosa, n. 13, 2020. Disponível em: https://revistarosa.com/2/roda-a-questao-racialno-brasil-em-perspectiva-historica (acesso em 07/12/2021).

SALLES, Ricardo (2008). E o Vale era o escravo: Vassouras, século XIX. Senhores e escravos no coração do Império. Rio de Janeiro: Civilização Brasileira.

SINGH, Nikhil (2017). “On Race, Violence, and 'So-Called Primitive Accumulation”. In: JOHNSON, Theresa; LUBIN, Alex (eds.). Futures of Black Radicalism. Londres/ Nova York: Verso.

TAUNAY, Carlos Augusto (2001 [1839]). Manual do Agricultor Brasileiro. São Paulo: Companhia das Letras.

TOMICH, Dale (2011). Pelo Prisma da Escravidão: Trabalho, Capital e Economia Mundial. São Paulo: Editora da Universidade de São Paulo.

VERNEK, Francisco (1847). Memória sobre a fundação de huma fazenda na Província do Rio de Janeiro. Rio de Janeiro: Typographia Universal de Laemmert.

VOGEL, Lise (2013 [1983]). Marxism and the oppression of women: toward a unitary theory. Boston: Brill.

WALLERSTEIN, Immanuel (1974). O Sistema Mundial Moderno - A agricultura capitalista e as origens da economia-mundo europeia no século XVI. Porto: Edições Afrontamento.

WALLERSTEIN, Immanuel (1979). The Capitalist World-Economy. New York: Cambridge University Press.

WERNECK, Luis (1865 [1855]). Idéas sobre colonisação precedidas de uma succinta exposição dos principios geraes que regem a população. Rio de Janeiro: Eduardo \& Henrique Laemmert.

WILLIAMS, Eric (1975 [1944]). Capitalismo e escravidão. Rio de Janeiro: Ed. Americana.

Recebido: 20/05/2021 | Aprovado: 26/10/2021 